・综述・

\title{
西南干旱河谷植物多样性资源的保护与利用
}

\author{
沈泽昊 ${ }^{1^{*}}$ 张志明 ${ }^{2}$ 胡金明 ${ }^{3}$ 韩 杰 $^{1}$ 杨济达 ${ }^{2}$ 应凌霄 ${ }^{1}$ \\ 1 (北京大学城市与环境学院生态学系, 地表过程分析与模拟教育部重点实验室, 北京 100871) \\ 2 (云南大学生态与环境学院, 昆明 650091) \\ 3 (云南大学国际河流与生态安全研究院, 昆明 650091)
}

\begin{abstract}
摘要: 西南干旱河谷是分布于我国亚热带横断山区的隐域性河谷景观, 其环境受季风气候、岭一谷地形环境和人类 开发活动的共同影响。适应于季节性干旱和垂直气候分异, 干旱河谷具有独特的植被和丰富的物种多样性资源。 在过去几十年中, 干旱河谷的气候变化以增温为一致特征, 同时经历着广泛的人类活动干扰, 特别是道路建设、水 利工程、矿山开发和城镇化驱动的土地利用变化, 造成了普遍的植被破坏、生境退化和生物入侵, 给乡土植物多 样性资源和生态系统稳定性带来了严重威胁, 然而至今对干旱河谷生物多样性的保护仍基本属于空白。因此, 建 议及时建立干旱河谷的生物多样性保护体系; 因地制宜采取退化植被修复、立体农业规划、特色植物资源利用和 风景旅游开发等措施, 以维持干旱河谷生态系统的可持续性; 落实生态文明建设的相关政策, 以保障西南生态屏 障的生态安全和生态服务能力。

关键词: 干旱河谷; 植物多样性; 气候变化; 土地利用; 环境胁迫; 生态系统保护; 资源利用; 政策
\end{abstract}

\section{Protection and utilization of plant biodiversity resources in dry valleys of Southwest China}

Zehao Shen ${ }^{1 *}$, Zhiming Zhang ${ }^{2}$, Jinming $\mathrm{Hu}^{3}$, Jie $\mathrm{Han}^{2}$, Jida Yang ${ }^{2}$, Lingxiao Ying ${ }^{1}$

1 Department of Ecology, College of Urban and Environmental Sciences, Key Laboratory for Earth Surface Processes of the Ministry of Education, Peking University, Beijing 100871

2 College of Ecology and Environment, Yunnan University, Kunming 650091

3 College of International River and Ecological Security, Yunnan University, Kunming 650091

\begin{abstract}
The dry valleys of Southwest China specifically refer to a type of azonal landscape distributed in the large river basins of the Hengduan Mountain ranges, and are the outcome of the effects of the monsoon climate, ridge-valley geomorphology, and long-term human perturbations. The dry valley landscape is characterized by prominent seasonal aridity, a vertical climate gradient, rich flora of high endemism, and unique vegetation types well adapted to the distinct environment. The environmental change in the last decades is characterized by consistent climate warming and widespread anthropogenic disturbances, especially land use/land cover changes mainly driven by road building, hydro-power construction, mining, and urbanization. These human disturbances intensified vegetation fragmentation, soil erosion, habitat degradation and biological invasion. Environmental degradation has threatened biodiversity resources and ecosystem security while the conservation measures for this unique ecosystem are lacking. We appeal for attention and timely action of biodiversity conservation in the dry valleys of Southwest China by means of establishing natural reserves. Meanwhile, contingent planning for vertical agriculture, degraded vegetation restoration, utilization program for the unique species resource and ecotourism are critical maintaining the sustainability of the dry valley ecosystems. Moreover, the policy and strategy under the goal of ecological civilization construction are also important tools to be applied in promoting ecosystem services and ecological security in the dry valleys of Southwest China.
\end{abstract}

收稿日期: 2016-01-21; 接受日期: 2016-04-13

基金项目: 国家自然科学基金(41371190)

* 通讯作者 Author for correspondence. E-mail: shzh@urban.pku.edu.cn 
Key words: dry valleys; plant diversity; climate change; land use; environmental stress; ecosystem conservation; resource utilization; policy

中国西南干旱河谷是横断山区及其南延山系 一种独特的自然景观和生态系统类型, 沿怒江、澜 沧江、元江、金沙江及其支流雅聋江、大渡河、岷 江、白龙江、白水江等河谷的部分地段分布(张荣祖, 1992)。干旱河谷植被景观的形成主要受到平行山脉 对西南和东南季风的水汽阻隔、深陷的河谷地形产 生的“焚风效应”等自然因素的控制(张荣祖, 1992; 何永榄等, 2000), 人类历史悠久的农牧业开发对原 生植被破坏、局部干旱加剧也具有深刻影响(许再富 等, 1985)。过去半个世纪以来, 气候温暖化和极端 气候事件频发, 在全球和区域尺度上加剧了对生态 系统的胁迫; 区域经济发展驱动下的人类活动在我 国西南干旱河谷地区也显著扩张。这两方面的变化 都成为本区域生物多样性和生态安全的关键胁迫 因子(孙辉等, 2005)。

适应于暖热干旱气候环境的植物种类不仅是 保护西南干旱河谷生态安全的重要资源, 也是利用 该区域独特自然环境和气候资源、实现区域可持续 发展的战略资源。为了保护这些分布狭窄、环境极 端、组成独特的宝贵生物多样性资源, 有必要就其 生存的自然环境条件和人为影响进行分析总结, 并 就其保护和可持续利用提出科学对策。

\section{1 干热河谷的资源环境特点}

按热量条件, 西南干旱河谷由南往北被分为 “干热”、“干暖”、“干温”3种类型(张谊光等, 1989)。 虽然各条河流的干旱河谷彼此隔离, 且大多距离遥 远，却呈现了相对一致的自然环境特点，即光热资 源丰富、干湿季分明、降水少而集中、海拔梯度显 著(景锐等, 2000)。

\section{1 光热资源丰富}

干旱河谷区光热资源丰富, 气温高于我国东部 同纬度地区。在深陷的河谷段形成一系列热点区域, 年生物温度的分布见图1 $\mathrm{a}$ 。根据长期气象观测记录, 南部和中部干热河谷区大于 $10^{\circ} \mathrm{C}$ 积温一般在 $7,000^{\circ} \mathrm{C}$ 以上, 相当于热带和南亚热带热量水平; 中 部干暖河谷区大于 $10^{\circ} \mathrm{C}$ 积温为 $4,500-7,000^{\circ} \mathrm{C}$, 相当 于中亚热带热量水平; 北部干温河谷区大于 $10^{\circ} \mathrm{C}$ 积
温为 $3,000-4,500^{\circ} \mathrm{C}$, 约相当于北亚热带热量水平 (刘伦辉和张建华, 1988; 张谊光等, 1989)。

干旱河谷地区全年光能资源变化范围在20-30 亿 $\mathrm{J} / \mathrm{m}^{2}$ 之间。干热河谷区全年光能资源达 $25-30$ 亿 $\mathrm{J} / \mathrm{m}^{2}$, 旱季和雨季各约占一半。西昌、得荣、巴塘、 汉源等地雨季光能略多于旱季, 生长季光能总量可 达 $15-20$ 亿 $\mathrm{J} / \mathrm{m}^{2}$ 。泸定、丹巴、南坪等地河谷区，全 年光热资源虽也可达 $20-30$ 亿 $\mathrm{J} / \mathrm{m}^{2}$ 之间，但植物生 长季仅在9-13亿 $\mathrm{J} / \mathrm{m}^{2}$ 之间, 是干旱河谷区光能资源 最少的地区(张荣祖, 1992)。

\section{2 季节性干旱}

干旱河谷区降水量少, 蒸发量是降雨量的 2-4 倍, 年均干燥度为 1.5-5.0。降雨年内分配不均, 主 要集中在夏季，旱季降水一般不足年降水的 $20 \%$, 特别是4-5月旱季末期, 气温高, 蒸发强烈, 土壤严 重干旱(张谊光等, 1989; 黄炬斌, 2010 ${ }^{\circledR}$ )。区域内降 水格局受西南季风和纵向岭谷地形的相互作用主 导, 在诸河流上游以及金沙江中游形成了若干个沿 河谷狭长延伸的显著干旱中心(图1b)。

\section{3 显著的环境海拔分异}

干旱河谷以森林植被的出现为上限，在不同河 段具有 $10^{2}-10^{3} \mathrm{~m}$ 的海拔差。其分布的海拔幅度主要 受“山脊-河谷”相对高差和具体地点水热环境的影 响。干旱河谷的气温垂直递减率一般比较大，降水 量一般随海拔升高呈明显增长趋势(张荣祖，1992; 陈利顶等, 2001; Yang et al, 2016), 导致土壤、植被 和农业系统也出现相应的海拔变化。如岷江上游, 从河谷到山顶可分为河谷暖温带半干旱气候 $(2,000$ $\mathrm{m}$ 以下)、温带半干旱河谷气候 $(2,000-2,500 \mathrm{~m})$ 、山 地寒温带湿润气候 $(2,500-3,000 \mathrm{~m})$ 、山地亚寒带气 候 $(3,000-4,000 \mathrm{~m})$ 以及高山高原高寒带气候带 (4,000 m以上)(杨钦周, 2007)。在金沙江干热河谷区, 谷底植被为稀树灌草丛，随着海拔升高，依次更替 为以常绿柇林为主的常绿阔叶林、云南松 (Pinus yunnanensis)林或松柇混交林、常绿润叶与落叶阔叶 混交林等(张宗锦等, 2006)。这样的立体环境还导致

(1) 黄炬斌 (2010) 成兰铁路沿线(峮江干热河谷段)植物多样性及其工 程扰动区植被恢复潜力研究. 硕士学位论文, 四川农业大学, 成都. 

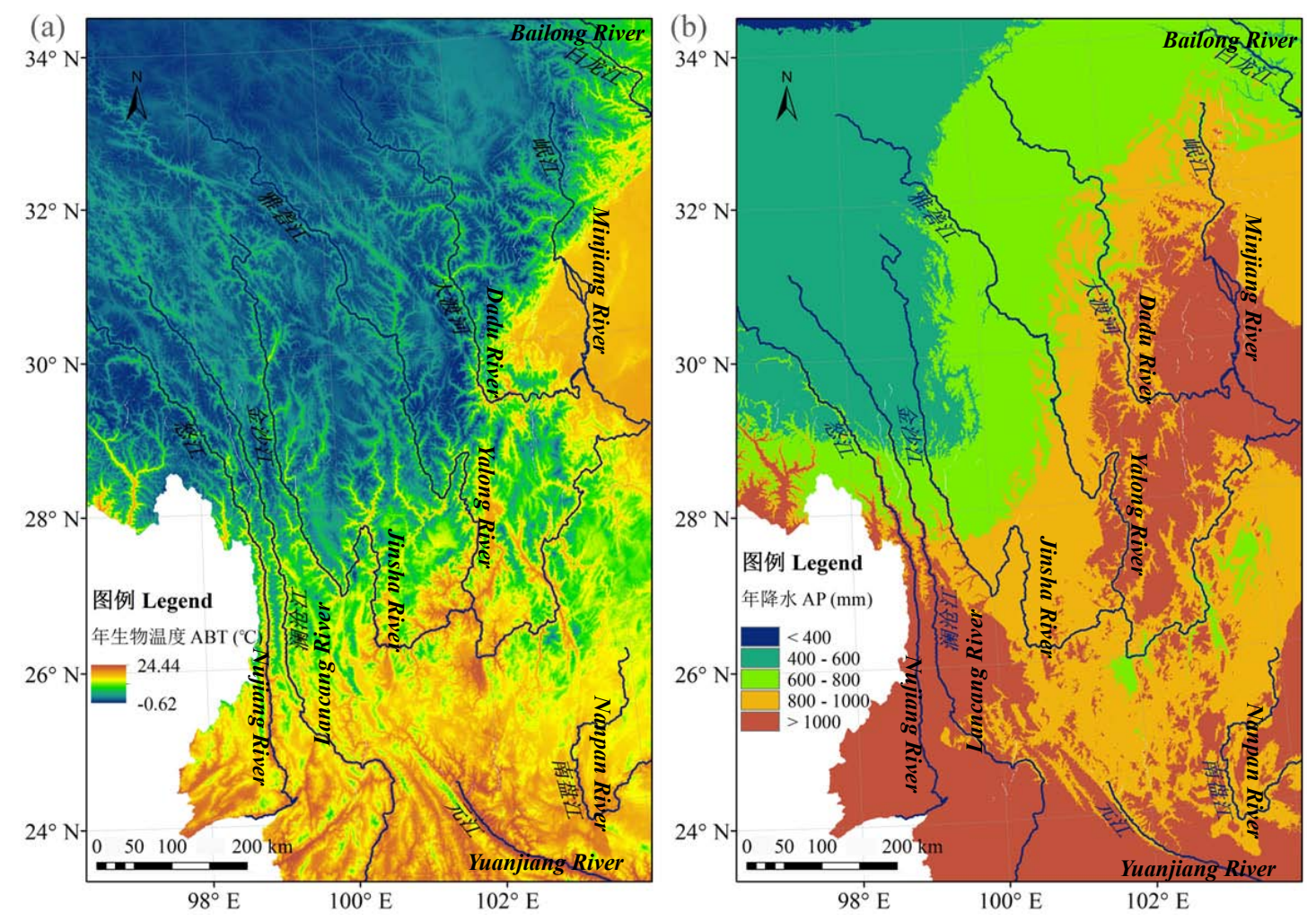

图1 我国西南地区气候特征空间格局。(a)年生物温度 $\left(\mathrm{ABT},{ }^{\circ} \mathrm{C}\right) ;(\mathrm{b})$ 年降水量 $(\mathrm{AP}, \mathrm{mm})$ 。据刘晔等 $(2016)$ 作图。

Fig. 1 The spatial pattern of climate features in Southwest China. (a) Annual biotic temperature (ABT, ${ }^{\circ} \mathrm{C}$ ); (b) Mean annual precipitation (AP, mm). Following Liu et al (2016).

了农业生产的立体分布，如峎山上游的“河谷林果 粮-半山农牧-高山林牧”的农业海拔分布格局(鲍 文, 2011)。

\section{4 土地资源缺乏}

干旱河谷谷坡陡峻，坡度常在 $30^{\circ}-40^{\circ}$ 甚至以 上。受地形和水资源影响, 适宜耕作的土地资源较 贵乏。耕地一般沿河谷呈带状分布, 且以坡耕地和 旱地为主(张宗锦等, 2006)。如岷江上游耕地仅占其 土地面积的 $2.5 \%, 25^{\circ}$ 以上陡坡耕地约占耕地面积 的 $21.46 \%$ (叶延琼等, 2002; 鲍文, 2011)。金沙江干 热河谷区的东川、会泽、大姚、宾川、元谋五县, 其 耕地面积仅占总面积的 $13.74 \%$ (拜得珍等, 2006)。

此外, 由于干旱河谷区地形陡峭、地质结构松 散, 滑坡、泥石流等地质灾害多发, 水土流失严重, 土层普遍较薄, 多砂石, 土壤贫痊, 保水保肥能力 差, 不利于农业生产(郭晓鸣, 2001)。如金沙江流域 的元谋县水土流失面积占全县国土面积的 $53.5 \%$ (纪 中华, 2009); 金沙江年均输沙量约占长江上游的一 半，达到 2.49 亿吨，而其泥沙约有 $70 \%$ 来自干热河
谷区(石承苍和雍国玮, 2001)。

\section{5 经济发展滞后}

相较而言, 干旱河谷区的交通、通讯和能源等 基础设施薄弱，科技、文教、卫生发展水平均低于 全国平均水平, 市场化程度较低。兼之土地资源匮 乏、干旱、土壤贫疹、水土流失严重等不利因素, 制 约了干旱河谷区生态经济发展(拜得珍等, 2006; 沙 毓沧等, 2006)。按照国家2014年标准, 区内68个县 级行政单位中约有国家级贫困县 40 个, 约占全国 572 个贫困县的 $7 \%$, 占区内全部县级行政单位的近 $2 / 3$, 社会经济发展明显滞后。

\section{2 植物物种多样性资源特点}

刘晔等(2016)根据对我国西南9条主要河流干 旱河谷的植被调查, 结合前人积累的植物分布数据 (金振洲和欧晓昆，2000; 金振洲，2002; 欧晓昆等, 2006), 共记录到典型干旱河谷地段分布的维管束 植物 186 科 1,016 属 2,794 种, 分别占中国维管束植物 科、属、种数的 $59.6 \%$ 、 $30.5 \%$ 和 $8.9 \%$, 其中有䓲类 
和石松类植物 29 科 56 属 165 种、裸子植物 4 科 12 属 20 种、被子植物 153 科948属2,609种。综合已有资料, 得到干旱河谷植物多样性资源特点如下:

(1)构成复杂但优势科、属明显。域内有 36 个仅 含单属单种的科和 520 个仅含单种的属, 分别占本区 总科数的 $19.35 \%$ 和总属数的 $51.18 \%$; 而种类最多的 前 5 个科即禾本科、菊科、蝶形花科、蓄薇科和唇形 科, 共占总属数的 $29.23 \%$ 和总种数的 $29.95 \%$ 。

(2)较强的热带区系亲缘。由于地势低洼、气候 干热, 干旱河谷植物区系属水平的热带成分与温带 成分的比值为 $2.56 \pm 2.24$ (均值土标准差), 明显高于 我国亚热带同纬度区域的平均水平 $(0.89 \pm 0.64$, 沈 泽昊和张新时, 2000), 在 $26^{\circ} \mathrm{N}$ 以南区域尤为明显 (图2); 而在科水平上, 干旱河谷植物区系中热带成 分与温带成分的比值更是高达3.16 \pm 1.41 , 表明干旱 河谷植物区系中热带成分保留更多, 其中, 泛热带 分布属和热带亚洲至热带非洲分布属是干热河谷 植被的主要成分(朱华, 2008)。

(3)种、属特有度差异大, 新特有性特征明显。 在维管束植物全部1,016属中只有16个中国特有属, 其 $1.6 \%$ 的特有率相对于我国亚热带 $4.7 \%$ 的平均水 平来说很低(沈泽昊和张新时, 2000), 但中国特有种 比例却高达 $61.9 \%$ (金振洲, 2002)。属、种水平特有 成分比例的悬殊差距表明, 干旱河谷环境足够特殊, 尽管形成的时间较短, 但自其形成以来保留和产生 了大量的中国或地区特有物种, 前者以古特有为主, 后者则多为干旱河谷之间隔离分化的新特有种, 如 金振洲(2002)确认了 46 个川滇干热河谷特有种。

(4)局地多样性较低, 但区域差异显著。干旱河 谷生境普遍植被稀疏, 植物物种 $\alpha$ 多样性一般较低, 只在一些湿润的局部生境残留的季雨林群落保留 了较高的物种丰富度(孙坌雯等, 2008; 顾伯健, $2015^{\circledR}$ )。由于河谷海拔梯度显著, 地形变化大, 植物 群落类型和物种构成变化大, $\beta$ 多样性较高; 不同河 流之间的物种构成差异是植物多样性仍较丰富的 主要原因(刘华等, 2016; Yang et al, 2016)。

(5)独特的资源植物。干旱河谷由于丰沛的热量 资源而造就了独特的乡土生物多样性资源。例如: 滇刺本(Ziziphus mauritiana) 是紫胶虫的主要寄主植

(1) 顾伯健 (2015) 云南绿汁江下游与元江干热河谷普漂段季雨林与萨 王纳植被的群落学研究. 硕士学位论文, 中国科学院西双版纳热带植物 园, 昆明.

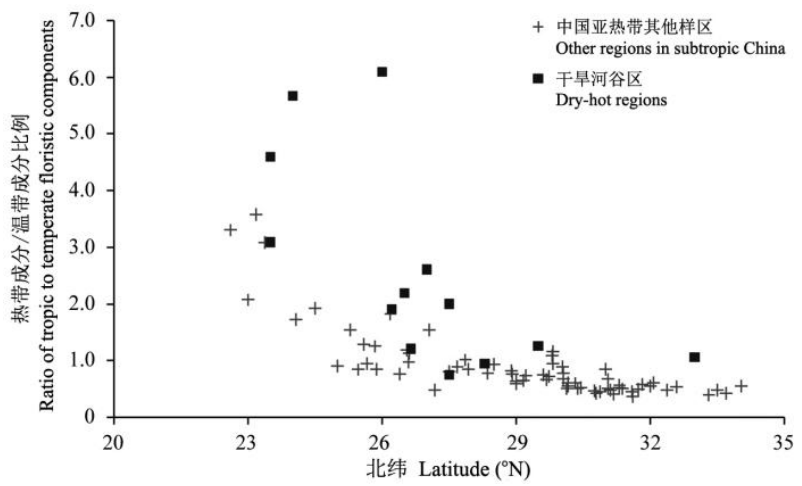

图2 西南干旱河谷及中国亚热带其他地区植物区系热带成 分与温带成分在属水平上的比值。数据分别来自刘晔等 (2016)和沈泽昊和张新时(2000)。

Fig. 2 The latitudinal pattern of the ratio of tropical over temperate floristic components at the generic level, compared between the sites of the dry-hot valleys of Southwest China (data from Liu et al, 2016) and other regions in the subtropical China (data from Shen \& Zhang, 2000)

物; 余甘子(Phyllanthus emblica)、酸角(Tamarindus indica)、滇刺苯等是制作饮料果脯等系列食品的野 生果树; 木棉 (Bombax malabaricum)、龙须草 (Eulaliopsis binata)、龙舌兰(Agare angustifolia)、剑 麻(A. sisalana)、火索麻(Helicteres iscra) 等是较好的 纤维植物; 金合欢 (Acacia famesiana) 、香茅 (Cymbopogon tortilis) 等是有开发价值的香料植物 (陈玉德等, 1990); 千张纸(Cullicapa arborea)、大叶 紫珠(Cullicapa arborea)、山黄麻(Trema orientalis)、 大叶斑鸿菊 (Vernonia vollcameraefolia)、膏桐 (Jatropha carcas)、刺天茄(Solanum indicum)、鸡嗉 子果 (Ficus semicordata) 等为药用植物, 是民间常用 的中草药。能源植物也是干热河谷植物资源的一大 优势, 如大戟科的膏桐、续随子(Euphorbia lathyris)、绿玉树(Euphorbia tirucalli), 均为富有潜力的 生物质能源物种(何璐等, 2008)。但是, 总体上来看, 干热河谷的植物资源开发还处于自发、分散的状况, 规模化和合理布局还有待提高。

\section{3 环境变化对生物多样性的影响}

\section{1 气候略有暖旱化趋势}

我们利用横断山区干旱河谷内 20 个典型气象 台站的长时序气候数据, 分析了研究区内 19702012年的气候变化趋势。结果表明: (1)全球变化背 景下, 平均气温总体呈现升高趋势, 升幅为 $0.11^{\circ} \mathrm{C} / 10$ 年, 较横断山区整体的 $0.15^{\circ} \mathrm{C} / 10$ 年略低, 
冬季升温幅度高于其他季节; (2)金沙江下游的元 谋、东川和巧家段河谷呈现持续降温趋势, 特别是 春季降温较为明显; (3)降水量呈微弱减少趋势, 为 $-1.48 \mathrm{~mm} / 10$ 年, 这主要是由于夏季降水减少量超 过其他季节降水增加量所致, 但区域差异明显, 其 中高海拔干温河谷近 20 年降水量有上升趋势(炉霍 站, 图3), 干暖河谷保持稳定(茂县站, 图3), 而元 江干热河谷近 30 年基本稳定, 只是近年略有下降 (元江站, 图3); (4)多数河谷站点年降水量的集中度 呈微弱下降趋势, 而集中期则有所提前, 但不明 显。此外, 干旱河谷区气候的相对湿度和日照时间 在近几十年间均呈现减少趋势, 相对湿度每 10 年约 减少 $0.16 \%$, 而日照时间则平均每 10 年减少 $24-26 \mathrm{~h}$ (丁文荣, 2013)。

\section{2 人为干扰与土地覆盖变化}

\subsection{1 道路建设}

当前, 公路建设在国民经济发展中起着越来越 重要的作用。据《中国生态问题报告》(环境保护部 自然保护司，1999), 交通基础设施建设与水利工程 建设已经成为我国破坏生物多样性的重要因素。分 布于横断山区及其南延山系的干旱河谷区域一方 面因为经济欠发达、公共基础设施相对落后, 是过 去20年国家投入的重点, 成为交通基础设施快速发 展的典型样本(姜睿等, 2013); 另一方面, 该地区又

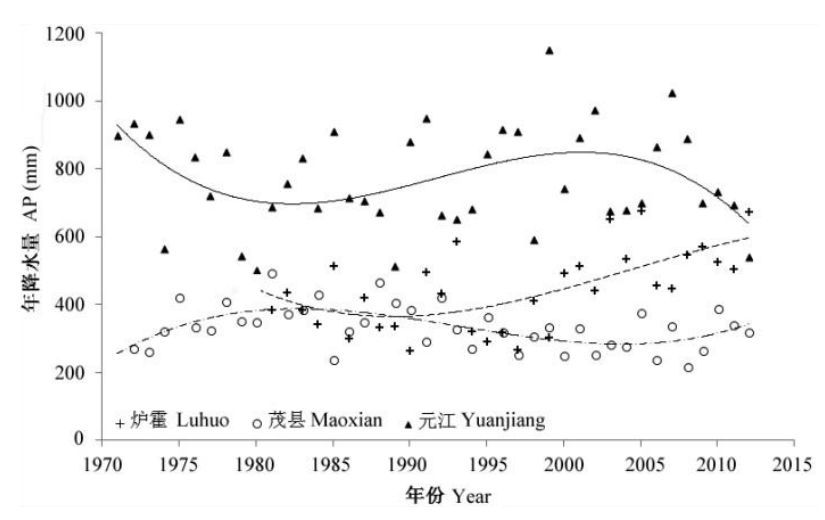

图3干旱河谷典型台站过去42年(1971-2012年)降水量的 变化趋势。炉霍 $(3,250 \mathrm{~m}$ a.s.l. $)$ 、茂县(1,590 m a.s.l.)、元江 (400 m a.s.l.)站分别代表了“干温”、“干暖”、“干热”河谷类型。 (数据来源: 国家气象信息中心)

Fig. 3 The trend of decadal dynamics of annual precipitation (AP) records in three meteorological stations of different dry valley types. Luhuo, Dry-temperate type; Maoxian, Dry-warm type; Yuanjiang, Dry-hot type. (Data source: the Chinese Meteorological Information Center)
是我国生物多样性资源的集中分布区，因而普遍面 临保护与发展的矛盾。特别是近十年来, 我国实施 了一系列惠农政策, “村村通公路”就是其中的一项, 有效打破了农村经济发展的交通瓶颈(陈建华, 2007)。以滇西北三江并流地区为例，作为世界自然 遗产地和多个自然保护区, 2005 年该地区道路总长 度为 $36,254.85 \mathrm{~km}$, 其中国道、省道、县道、乡村公 路分别占总长度的 $2.2 \% 、 4.7 \% 、 13.4 \%$ 和 $79.7 \%$; 而 在1989-2005年的16年间道路总长度增加了 $56.4 \%$, 上述 4 级公路的长度增量分别为 $38.9 \% 、 26.1 \%$ 、 $26.4 \%$ 和 $65.9 \%$ (Ying et al, 2014)。由于乡村公路一 般延伸到更为偏僻、陡峭的乡村, 其长度数倍至数 十倍于高等级公路, 加上投资强度不够, 道路建设 中植被保护和弃渣处理往往不能达标, 因此所带来 的地表植被破坏和水土流失也远远高于高等级公 路建设的影响(蒋春燕, 2010)。

而拥有全国最长公路里程的云南省, 2015年各 级公路已达 23.6 万 $\mathrm{km}$, 其中农村公路总长 19.7 万 $\mathrm{km}$ 。据中新网报道, 2010-2015年期间云南省新增公 路 2.6 万 $\mathrm{km}$, 除 $1,375 \mathrm{~km}$ 高速路外, 其余为低等级公 路; 2005-2010年期间, 云南全省改建和新建乡村公 路达10.1万 km (www.chinanews.com/df/2016/0110/7709855.shtml)。

在交通基础设施迅速改善的同时, 路建工程对 生态和环境产生了诸多负面效应, 主要包括: (1)对 植被的影响: 由于清除了地表的原有植被, 完全改 变了地表覆被甚至局部地形, 增加了土壤裸露并加 剧了土壤侵蚀和水土流失, 并通过路域次生生境和 交通工具的携带作用, 为杂草和外来植物入侵提供 了机会(Tikka et al, 2001; 刘晔等, 2013); (2)对动物 的影响: 包括交通致死(Forman \& Alexander, 1998), 以及干扰、阻断动物原有移徙路径而使之产生生境 回避和巢区转移等行为 (Forman \& Deblinger, 2000)。(3)理化环境影响: 包括改变土壤密度和路域 小气候, 路面材料和交通车辆释放固、液、气态污 染物而影响周边土壤(Trombulak \& Frissell, 2000); 有机物和重金属污染还通过地表径流影响周围水 体和水生生物群落(李月辉等, 2003)。

\subsection{2 水利工程与土地淹没}

西南干旱河谷因其独特的高山峡谷地貌常常 成为水电开发中坝址的首选之地, 西南重大水电工 程也大多位于干旱河谷区(李少丽等, 2007)。由于大 
河上游来水量大, 加上干旱河谷段地形落差大, 水 能资源十分丰富。例如, 金沙江径流年际变化小, 多年平均流量 $4,920 \mathrm{~m}^{3} / \mathrm{s}$, 年径流量 1,550 亿 $\mathrm{m}^{3}$, 水 能蕴藏量达 1.124 亿千瓦, 约占全国的 $16.7 \%$, 是全 国最大的水电能源基地，也是世界上少有的水能资 源富集的河流。目前金沙江上游川藏段共规划了 8 个梯级水电站, 初步规划装机容量 898 万千瓦; 中 游有 8 座巨型梯级水电站, 总装机容量为 2,058 万千 瓦; 下游则有溪洛渡、向家坝等4座世界级巨型梯级 水电站, 规划的总装机容量为 4,210 万千瓦, 年发电 量为 1,843 亿度, 规模相当于两个长江三峡电站(周 家骢, 2011)。在澜沧江云南省境内干流河段也规划 了14座水电站，包括功果桥、漫湾等8座梯级电站。 随着这些水电工程的逐步实施, 干旱河谷敏感脆弱 的生态系统将面临更为强烈的干扰。

水电工程对当地环境有一定的正面影响, 主要 表现为建成后库区水流变缓, 水库周边形成大面积 消落区湿地, 可改善局地气候条件, 特别是增加空 气湿度和降雨量, 有利于河谷地带植被的生长(周 家骢, 2011)。但负面影响也很显著, 主要包括: (1) 水库建成后形成大面积永久性水域, 对干旱河谷生 态系统及其特有物种的生境造成巨大损失。(2)河流 转变为静止水面, 对适应河流生境的水生生物将带 来灾难性影响, 这种负面效应因西南诸大河流都有 丰富的特有鱼类资源尤显突出。(3)在降水和水库水 位周期性涨落的作用下, 消落带坡面植被和土壤结 构将被破坏, 水土流失加剧, 常常导致局部地质灾 害的发生(杨慎勤, 2003; 王勇等, 2009)。(4)由于原 来适应陆生环境的植物种被淹没而消亡, 而水生物 种大多又不适应消落带周期性淹没的生境, 导致消 落带往往大面积裸露, 生态系统结构简单化, 稳定 性差, 再加上垃圾、废水污染而难以利用和恢复( ᄀ 承泰, 1999; 穆军等, 2008)。(5)水库建设产生大量移 民, 在干旱河谷区内的移民安置区建设和后期不可 避免的二次土地开发对脆弱的生态系统也会带来 严重威胁(林霖, 2011)。因此, 保护干热河谷库区脆 弱的生态环境, 减少水土流失, 恢复重建植被已成 为促进水电开发与生态环境协调发展的当务之急 (李少丽等, 2007)。

\subsection{3 矿山开发}

干旱河谷地区地质基础复杂, 矿产资源丰富多 样。如澜沧江流域兰坪金顶铅锌矿储量在1992年分
别占中国及云南省铅储量的 $7.5 \%$ 和 $47.35 \%$, 锌储量 的 $13.9 \%$ 和65\% (童海京和曾广权, 1995)。怒江河谷 贡山县茨开至丙中洛段富存高品位的铇、锡、羊脂 玉等矿产。金沙江下游的攀西和三江巨型成矿带储 藏着丰富的铅、锌、铁、铜、煤、磷等矿产。雅䶭 江河谷九龙段则储有铜、铅、锌、铍、铇、金、硫、 铁、大理石、石棉、水晶石、花岗石、汉白玉、绿 柱石等二十余种矿产资源, 尤以铜、铅和锌储量多, 品位高, 具有较高的开采价值。岷江上游地区的矿 产开发自20世纪初即已开始，除金矿外还有大量 煤、锑、铜、硝等矿藏。

矿产资源开发对环境的影响主要是开采过程 对地表的破坏, 以及开采、加工过程产生的环境污 染, 特别是排放的废气、废水、废渣中所含重金属 (镉、铅、砷)对土壤和水体的污染(李璇琼, 2013)。 在干旱河谷地区，限于技术、资金等因素，矿产资 源的开发缺乏统一规划和管理。由于未能严格执行 国家有关法规，矿山盲目开发一方面导致资源浪 费, 另一方面由于尾矿废渣沿山坡倾泻、掩埋地表 植被、污染河流的现象比较普遍, 植被保护和恢复 被忽视, 致使矿区水土流失十分严重(刘刚等, 2007), 甚至造成山体滑坡和泥石流。

\subsection{4 城镇发展与土地覆盖变化}

干旱河谷降水稀缺, 地形陡峭, 总体上地广人 稀。在较长的时间尺度上, 人类活动总体上呈加剧 趋势, 这在元江河谷过去 500 年的植被覆盖率变化 中得到体现(许再富等, 1985)。但由于自然环境比较 恶劣, 人类活动强度在多数地区变化较为缓慢, 景 观的变化相应也因地而异, 总体上并不剧烈 (Moseley和唐亚, 2006)。针对位于金沙江流域干早 河谷的宾川县(杨子生等, 2004)、得荣县(李苗裔等, 2012)、元谋盆地(何锦峰等, 2009)、滇藏公路沿线 (Liang et al, 2014)等多个区段的土地利用/覆被变化 研究得到了大体一致的结果。在过去 40 年里, 建筑 面积扩张在所有流域的干旱河谷区均为最显著的 现象, 尽管建筑区总面积的比例并不大, 但也反映 了城镇化过程的存在。由于城镇面积一般向耕地扩 张, 并推动新的土地开虎, 林地、灌草丛、未利用 地和耕地等几种类型之间常常出现相互转换, 并引 起景观格局破碎化程度的年际波动或空间上的异 质变化(李苗裔等, 2012; Liang et al, 2014)。在澜沧 江流域也观察到类似的土地利用变化特征(许建初 
等, 2003)。另一方面, 天然森林普遍存在显著退化 的现象, 如面积缩小、片断化程度加剧(欧晓昆, 1994; 杨万勤等, 2002; Liang et al, 2014)。但自2000 年以来, 国家在天然林保护、生态修复工程和人工 经济林发展等方面加大了投入, 因此林地总面积呈 现先降后升或变化不大的动态特征(周旭等, 2010)。

\section{4 生物多样性资源保护与可持续利用对策}

\section{1 建设干旱河谷自然保护区, 保护原生生态系统}

干旱河谷典型植被类型包括干热的河谷型稀 树灌草从和肉质灌从、干暖的小叶灌从和干温的近 荒漠植被, 具有独特的群落特征和植物区系组成, 是我国西南河谷地区特有的植被类型, 也是全球萨 王纳植被、地中海型马基植被在中国西南地区的残 余和替代类型。在强盛的亚洲季风影响下, 中国热 带亚热带陆地景观的基质为湿润森林。由季风气候 与西南平行岭谷地貌相互作用形成的这几种非地 带性(或隐域)植被类型(吴征镒, 1980)是全球热带、 亚热带半干旱气候与植被类型在中国的唯一代表, 分布狭窄且地理分异明显, 其中保存着大量的干旱 河谷特有植物种(金振洲和欧晓昆, 2000)和一些特 有动物种, 如金沙江上游白马雪山一带的矮岩羊 (Pseudois schaeferi) (格玛嘉措, 2000), 具有不可替 代的保护价值。然而, 这类生态系统虽因人类活动 干扰而受到不同程度的威胁, 至今却基本处于我国 现有的自然保护区体系之外。因此, 非常有必要选 择干旱河谷景观完整和植被保存良好的区段, 针对 这几种珍稀植被类型及其生物多样性建立自然保 护区。

\section{2 退化植被修复与生态重建}

西南干旱河谷的现存植被普遍具有次生特征 (许再富等, 1985)。多数研究认为, 该区域存在随着 移民迁入垦殖和砍伐林木, 森林覆盖率急剧降低和 逐渐旱化的过程, 如四川西昌与云南元谋“土林”的 形成。尽管如此, 干旱河谷的典型现状植被例如半 稀树草原, 已具有较长的历史和相当的稳定性, 被 称为偏途顶极群落(欧晓昆, 1994)。因此植被恢复的 指导思想应以绿化荒山、恢复生境为主, 宜林则林、 宜灌则灌、宜草则草(陈国阶, 2000)。植被恢复的主 要措施包括封山育草, 改变小生境; 优先选用乡土 树种; 改进造林技术和整地方法; 营造混交林为主 等(张有富, 1998; 张信宝等, 2003; 李昆等, 2004)。
另一方面, 针对不合理的土地开唇, 应结合植被恢 复, 继续加强土地利用方式调整, 缓坡耕地进行 “坡改梯”, 陡坡地退耕还林, 以减轻水土流失和土 地退化(李昆等, 2011)。

\section{3 开发因地制宜的立体农业模式}

立体农业是一种利用垂直空间资源的生产方 式, 通过建立多层次配置、多种生物共栖的立体种 植或种植、养殖结合形式，充分利用光热资源的时 空分异和不同物种的需求, 以提高单位面积生产力 (范明，1992；孙亚明，2013)。干旱河谷区丰富的光 热资源和沿海拔气候梯度为发展立体农业提供了 有利条件。因地制宜, 将农业开发、植被恢复和水 土保持有机结合是干旱河谷土地开发的核心战略 (于丽娟和杜长江, 2008)。

(1)应根据热量条件的差异, 将干旱河谷区按海 拔高度划分成干热、干暖、干温、干凉等类型，分 别制定相应的农业种植养殖模式(杨勤业等, 1988)。 (2)由于水资源是限制干旱河谷区农业发展的关键, 应按水源条件规划不同的农业发展模式和水源保 障体系(纪中华等, 2003)。由于地形坡度决定水分和 土壤养分条件, 应将 $<15^{\circ}$ 的沿河低平地、有灌溉条 件的高台地和缓坡地建成高产农业区; $<25^{\circ}$ 的谷坡 地建设为经济林果用地; $>25^{\circ}$ 的部分土层较厚、条 件较好的坡地作为经济林和放牧用地; 对坡度 $>25^{\circ}$ 、海拔 $>3,000 \mathrm{~m}$ 的部分坡地退耕还林还草, 形 成干旱河谷的土地利用立体格局(鲍文，2011)。(3) 在相同地点, 农业系统模式设计和作物选择要考虑 作物之间的需求差异和光热水土资源的竞争与互 补, 同时兼顾市场需求(陈利顶等, 2001)。如针对元 谋干热河谷区, 张建平和王道杰(2000)提出在海拔 900-1,100 m平坝区发展粮食和蔬菜基地的复合模 式; 在1,100-1,350 m低山丘陵区发展种植业-畜牧 业复合农业生态系统模式; 在1,350-1,600 m中低山 发展粮一经-果-畜复合农林系统; 在 $1,600 \mathrm{~m}$ 以上中 高山区发展森林一林副产品系统为主的模式。实践 证明, 旱坡地复合农业立体种植模式能有效地减少 高强度降雨引起的水土流失, 降低土壤侵蚀强度和 径流含沙量, 提高旱季土壤含水量, 改善局地小气 候，产生良好的经济和社会效益(杨艳鲜等，2005, 2006; 何璐等, 2006)。

\section{4 开发利用与推广特色资源植物}

干旱河谷区的植物物种资源具有很强的地域 
性特征, 并且适应于光热资源充足和水分限制的特 殊生境条件; 同时西南少数民族具有丰富的药用植 物和经济植物开发利用历史。因此, 结合生物资源 分布的特点以及民族居住和文化的相关性, 深入挖 掘和研究, 必定会丰富其生物多样性价值的内涵 (彭华, 2001)。

目前，本地区特色植物资源的开发普遍受到3 个因素的制约。(1)使用价值没有得到深入研究。只 有通过科学研究, 充分认识相关资源植物的食用、 药用或其他开发价值，才可能获得投资吸引力。(2) 缺乏深度开发利用技术和高效扩大繁殖技术。只有 达到足够的产品附加值, 才可能调动市场生产的积 极性。(3)缺乏合理配置不同植物资源开发、提高土 地利用效率、降低开发成本、减轻市场和环境风险 的科学规划。一些很有潜力的资源植物的开发在市 场短期行为的驱使下, 往往一哄而上又一哄而散, 不能形成可持续的发展。三七、玛咖、葡萄种植都 出现过类似的情况。

\section{5 保护与开发干旱河谷风景旅游资源}

干旱河谷作为西南地区的一种奇异景观早在 一个世纪以前即引起世人的关注, 并吸引了西方探 险家的目光(Moseley和唐亚, 2006)。事实上, 这一独 特的景观和文化资源蕴藏着巨大的开发潜力, 为保 护其生物多样性与生态系统稳定性提供了一个可 持续的替代选择。

首先，这一区域内的自然风光独特、无可替代。 以三江并流世界遗产地为代表, 蓝天白云之下的高 山峡谷气势磅礴, 喷涌奔流的大江与稀树草地形成 强烈对比。更有如“怒江第一湾”、“金沙江第一湾”、 虎跳峡、金沙江畔的元谋土林、攀枝花苏铁(Cycas panzhihuaensis) 林等景点举世闻名; 滇金丝猴 (Rhinopithecus bieti)、白马鸡(Crossoptilon crossoptilon)等珍稀物种和成片的秃杉 (Taiwania cryptomerioides)林、红豆杉(Taxus chinensis)林独具特 色。在人文方面，干旱河谷区同时也是多民族聚居 区，灿烂多姿的民族文化是另一笔重要的旅游资 源。各式各样的民居建筑、民族服饰、特色饮食、 民族节庆活动和风土人情汇聚这一区域，并且沿海 拔梯度形成格局分化。如在滇西北, 从河谷到高山 依次分布着傈傈族、怒族、彝族、藏族等少数民族。 汉民族的历史文化在整个横断山区干旱河谷也同 样丰富多彩、历史悠久, 茶马古道即是其中的代表。
不仅如此，现代文明同样增添新的特色，如澜沧江 梯级水电站形成高峡平湖和高坝风光, 钻洞架桥的 高速公路穿越天然植被的五彩画廊(杨兰英和王珏, 2000)。尤为重要的是, 干旱河谷是横断山区交通网 络的必经之地，具有独特优越的交通条件; 沿线城 镇也是区内各种特色产品的集散地。因此, 干旱河 谷地区的生态旅游已经具备十分全面、理想的发展 条件和基础。生态旅游不仅可以带来区域发展亟需 的资金、技术和信息，也有助于自然保护意识的培 养和推广, 为社会-经济-生态可持续发展增加新的 活力。

为了解决旅游业经济利益与环境及传统文化 保护需求之间的矛盾，协调开发与保护的平衡，旅 游发展需要注意: (1)进行全面系统的环境承载力和 环境影响评估; (2)建立完善生态旅游规划体系, 并 依照自然景观进行合理布局; (3)旅游业者的监管与 旅游者自然保护意识的双重强化(吕永龙，1998; 牛 亚菲, 1999)。

\section{5 政策支撑}

党的“十八大”将“生态文明”正式确立为“五个 文明建设”的国家发展战略目标之一, 为生物多样 性与生态系统的保护与利用提供了国家制度保障 和实践纲领。因此，应当针对西南干旱河谷独特的 资源和环境, 总结和保护人类在适应这种独特环境 中长期积累的认知和生存策略, 并通过科学规划, 确立干旱河谷地区的生态文明建设战略。主要应当 包括: (1)建立干旱河谷生物多样性保护区(地)体系, 以保护干旱河谷景观的完整性和代表性生物群落和 典型生境, 以及干旱河谷动植物区系; (2)保护当地 居民(特别是少数民族)长期积累的生态文化，特别 是生物多样性资源可持续利用知识体系和技术模式, 并加以总结推广; (3)在人类活动驱动的气候干暖化 和景观破碎化现状之下，科学规划土地利用类型与 布局, 加强干旱河谷退化植被的生态修复与重建。

这些战略目标的达成, 需要充分合理利用国家 相关政策提供的制度保障。

\section{1 生态功能区划与生态红线政策}

2015年11月，国家环境保护部进行了全国生态 功能区划修编，将西南干旱河谷区划归生物多样性 保护、水源涵养和土壤保持区，明确指出川滇干热 河谷为全国和区域生态安全重要作用的土壤保持 
生态功能区(环境保护部, 2015)。尤其是云南省, 其 $2 / 3$ 的面积划为生物多样性保护区(环境保护部, 2015)。据此, 云南省生态功能区划将主要干旱河谷 划分为水土保持区(即土壤保持区)和生物多样性保 护区, 如I4-1红河下游低山河谷生物多样性生态功 能区、II3-1澜沧江干流中山峡谷水土保持生态功能 区、II4-2元江干热河谷水土保持与林业生态功能 区、III2-5金沙江、小江高山峡谷水土保持生态功能 区、III3-1香格里拉金沙江峡谷生物多样性保护生态 功能区、III4-1牛栏江、金沙江高山峡谷水土保持生 态功能区、III5-1澜沧江高山峡谷水土保持生态功能 区、III7-3澜沧江中游水土保持生态功能区等(李东 梅等, 2010; 云南省环境保护厅, 2014)。

为加强生态保护, 构建区域生态安全格局, 2011年《国务院关于加强环境保护重点工作的意 见》(国发[2011]35号)中明确提出, 在重要生态功能 区、陆地和海洋生态环境敏感区、脆弱区等区域划 定生态红线(高吉喜, 2015)。2015年党的十八届三中 全会把划定生态保护红线作为改革生态环境管理 体制、推进生态文明制度建设的重要举措之一。生 态保护红线划定工作又被列入我国生态文明建设 的纲领性文件和实施方案之中, 已进入各级政府实 质性推进阶段(高吉喜, 2015)。在省级主体功能区规 划的基础上, 建立生态红线管控制度, 截至2015年 底该项工作还在进行中。建议政府在划定生态红线 的过程中依据全国生态功能区划, 对干旱河谷区流 域生态系统功能、生态敏感性等进行定量评估, 将 重要且敏感的区域及当前保护空缺区纳入生态保 护红线区。

\section{2 生态补偿政策}

随着我国经济近30年的快速发展, 生态环境问 题越来越突出, 生态补偿作为平衡保护与发展的一 个政策工具日益受到重视(李碧洁等, 2013)。1998年 以来, 我国政府先后在《森林法》、《水污染防治法》 和《水土保持法》中明确提出相关的国家生态效益 补偿制度。2010年, 由国家发改委牵头组织的我国 首部《生态补偿条例》草案成型, 共提出湿地、生 态功能区等七大补偿范围。目前, 我国首部《生态 补偿法》正在酛酿之中。与此同时, 全国各地正在 推进生态补偿的实践试点, 也相继出台了流域、自 然保护区和矿产资源开发等方面的生态补偿政策
性文件, 但受政策法规建设的局限, 我国生态补偿 机制还存在着范围不明确、标准不科学、模式比较 单一、资金来源缺乏等问题。

西南干旱河谷属于对全国和区域生态安全具 有重要作用的土壤保持生态功能区。针对这一生态 功能区, 提出的保护措施有 “继续实施退耕还林还 草; 对已遭受破坏的生态系统, 实施生态恢复与建 设工程”(环境保护部, 2015), 该工程是我国实施生 态补偿的重要措施之一(李碧洁等, 2013)。西南干早 河谷区多为少数民族聚居, 生产、生活、教育及医 疗等方面的条件比较落后。尽管当前实施的退耕还 林和天然林保护工程的生态补偿对该区域居民生 活和生态恢复起到了积极作用, 但补偿力度和效果 都非常有限, 各种无序开发带来的生态和环境问题 仍然十分突出。因此有必要针对性地建立更加完善 的生态补偿机制(乔旭宁等, 2012; 王军锋和侯超波, 2013), 如李晓冰(2009)建议建立金沙江流域生态补 偿机制, 由长江下游经济发达区域对上游经济欠发 达的金沙江流域进行生态补偿, 协调发展, 提出了 资金、实物和政策3种补偿方式，等等。

针对西南干旱河谷这一特殊区域的生态补偿, 需要明确以下几个方面: (1)确定区域或者流域生态 补偿的各利益做关方, 即责任主体; (2)明确谁来补 偿, 如从利用流域水资源、土地资源及生物资源中 大量受益并对生态系统和环境产生影响的实体; (3) 确定补偿的客体, 该客体应该是执行区域或流域生 态保护工作, 对保障生态系统健康和水资源可持续 利用做出贡献的实体，如上游及周边区域的社区居 民, 以及相关的企事业单位等等; (4)补偿方式和途 径, 如资金、实物、政策补偿等, 实行征收或者减 免生态补偿税机制、建立补偿基金、实行信贷优惠 政策及国际合作补偿机制; (5)补偿标准的核算, 主 要包括两个方面: 一是为维持区域和流域生态系统 健康与服务的直接投入, 如修复植被、保护生物多 样性、减少和治理污染、改良土壤、修建水利设施 等等; 二是为了维护区域和流域生态系统健康与服 务而丧失发展机会的损失，即间接投入。总体而言， 如何很好地解决生态补偿的 3 个主要问题即“谁来 补偿、补偿多少、如何补偿” 是非常复杂的系统工 程, 需要综合生态、社会、经济、法律等方面一起 研究、协调和执行来完成。 


\section{3 生态移民政策}

生态移民(ecomigration)亦称环境移民，系指为 了保护一个地区特殊的生态环境, 或让一个地区受 损退化的生态系统得到修复而进行的移民(孟琳琳 和包智明, 2004)。生态移民是我国西部大开发战略 之一, 以实现恢复生态、扶贫开发双重目标(张云雁, 2011)。移民是当前干旱河谷区发展中难以避免的问 题。首先, 干旱河谷区地质灾害多发, 灾害发生及 发生的风险可产生移民; 其次, 城镇化过程需大量 建设用地, 必然产生失地的农村移民; 第三, 干旱 河谷区是我国重要的水电开发基地, 干流大型梯级 水电开发已经并将继续产生大量水电移民。如金沙 江流域向家坝水电站建成即产生库区移民约 9 万 人。移民安置将影响移民的长远生计、社会的稳定 以及当地生态环境的保护。

我国从2000年开始实施生态移民, 并颁布了全 国《易地扶贫搬迁“十一五”规划》。除相关领域的政 策法规外，国家已针对生态移民制定了《退耕还林 条例》和《关于易地扶贫搬迁试点工程的实施意见》 等管理规范, 地方各级政府也在十多年生态移民实 践中陆续制定了一些政策和管理条例, 但目前仍缺 乏专门针对生态移民的法律, 包括生态补偿法。干 旱河谷区的生态容量有限而环境脆弱, 由于水电梯 级开发、城镇和道路工程建设造成大量生态移民, 并可导致后续二次土地开发, 由此给干旱河谷生态 系统带来的胁迫形势十分严峻。因此, 生态移民相 关的政策法规对于干旱河谷生物多样性保护与可 持续发展是意义重大、亟待建设的管理工具。

\section{参考文献}

Bai DZ, Pan ZX, Ji ZH, Yang YX, Fang HD, Liao CF (2006) The problem and the countermeasures of ecological environment in Jinsha River dry valley. Territory \& Natural Resources Study, (4), 50-51. (in Chinese with English abstract) [拜得珍, 潘志贤, 纪中华, 杨艳鲜, 方海东, 廖承飞 (2006) 浅议金沙江干热河谷生态环境问题及治理措施. 国土与自然资源研究, (4), 50-51.]

Bao W (2011) Impact of climate change on agriculture on dry valley in the dry upper reaches valley of Minjiang River and its adaptive countermeasures. Guangdong Agricultural Sciences, 38, 162-165. (in Chinese with English abstract) [鲍 文 (2011) 峎江上游干旱河谷气候变化对农业发展的影 响及适应性对策. 广东农业科学, 38, 162-165.]

Chen GJ (2000) Thoughts on ecologic construction in the upper reaches of the Changjiang River. Science \& Technology Review, (7), 59-61. (in Chinese) [陈国阶 (2000) 关于长江
上游生态建设的几点思考. 科技导报, (7), 59-61.]

Chen JH (2007) Reflection on the problems of rural road construction in the village. Science Information, (3), 231-237. (in Chinese) [陈建华 (2007) 农村公路“村村通”建设中存 在问题的思考. 科技信息, (3), 231-237.]

Chen LD, Wang J, Fu BJ (2001) Strategy on sustainable development of eco-fragile area of xerothermic valley in Southwest China. China Soft Science, (6), 95-99. (in Chinese with English abstract) [陈利顶, 王军, 傅伯杰 (2001) 我国西南干热河谷脆弱生态区可持续发展策略. 中国软 科学, (6), 95-99.]

Chen YD, Zhang ZJ, Hui YW, Zheng DR, Tan BB, Ding WA (1990) Study on the full use of plant resources of dry-hot valley in Yunnan. Forest Research, 3, 638-641. (in Chinese with English abstract) [陈玉德, 张志钧, 惠雅雯, 郑德蓉, 谭保邦, 丁维安 (1990) 云南干热河谷的植物资源及开 发利用研究. 林业科学研究, 3, 638-641.]

Department of Nature Conservation, Ministry of Environmental Protection (1999) Report on the Ecological Problems in China. China Environmental Science Press, Beijing. (in Chinese) [环境保护部自然保护司 (1999) 中国生态问题 报告. 中国环境科学出版社, 北京.]

Diao CT (1999) Preliminary study on land resource of water level fluctuating zone in the Three Gorges Reservoir. Resources and Environment in the Yangtze Basin, 8, 75-79. (in Chinese with English abstract) [刀承泰 (1999) 三峡水库 水位消落带土地资源的初步研究. 长江流域资源与环境, 8, 75-79.]

Ding WR (2013) Trend of the climate changes in dry valleys of Hengduan Mountains, China. Journal of Ecology and Rural Environment, 29, 681-687. (in Chinese with English abstract) [丁文荣 (2013) 横断山区干旱河谷气候变化趋势 研究. 生态与农村环境学报, 29, 681-687.]

Forman RTT, Alexander LE (1998) Roads and their major ecological effects. Annual Review of Ecology and Systematics, 29, 207-231.

Forman RTT, Deblinger RD (2000) The ecological road-effect zone of a Massachusetts (USA) suburban highway. Conservation Biology, 14, 36-46.

Fan M (1992) On the comprehensive multi-story and dimension agriculture. Journal of Natural Resources, 2, 180-188. (in Chinese) [范明 (1992) 试论立体农业. 自然资源学报, 2, 180-188.]

Gao JX (2015) Exploring the delineation and supervision of ecological protection redlines in China. Biodiversity Science, 23, 705-707. (in Chinese with English abstract) [高吉 喜 (2015) 探索我国生态保护红线划定与监管. 生物多 样性, 23, 705-707.]

Gemajiacuo (2000) The Pseudois schaeferi in the Baima Snow Mountain. Chinese Wildlife, (4), 41. (in Chinese)[格玛嘉措 (2000) 白马雪山的矮岩羊. 野生动物学报, (4), 41.]

Guo XM (2001) The main problems and countermeasures of ecological construction in arid valley area of Sichuan Province. Social Science Research, 5, 33-36. (in Chinese) [郭晓 
鸣 (2001) 四川干旱河谷地区生态建设的主要问题与对 策建议. 社会科学研究, 5, 33-36.]

He JF, Su CJ, Shu L, Yang Z (2009) A 3S-based study on land use and land cover change in the Jinshajiang xerothermic valley: a case of Yuanmou County, Yunnan Province. Journal of Mountain Science, 3, 341-348. (in Chinese with English abstract) [何锦峰, 苏春江, 舒兰, 杨忠 (2009) 基于 $3 \mathrm{~S}$ 技术的金沙江干热河谷区 LUCC研究: 以云南省元 谋县为例. 山地学报, 3, 341-348.]

He L, Duan YT, Sha YC, Luo JP, Qu WL, Ma KH, Zhang D (2006) Study on ecology and economy benefit of eco-economic forestry composite planting mode in Jinsha River hot and dry valley. Journal of Soil and Water Conservation, 20(5), 16-19. (in Chinese with English abstract) [何 璐, 段曰汤, 沙毓沧, 罗敬萍, 睢文林, 马开华, 张德 (2006) 金沙江干热河谷区生态经济林复合种植模式的生 态经济效益研究. 水土保持学报, 20(5), 16-19.]

He L, Yuan LC, Duan YT, Sha SC, Yang SL, Huang WY, Gou $\mathrm{P}, \mathrm{Wu} \mathrm{K}$, Chen XY (2008) Exploitation and utilization of energy plants in the dry-hot valley in Yunnan. China Tropical Agriculture, (1), 33-35. (in Chinese) [何璐, 袁理春, 段 曰汤, 沙毓沧, 杨顺林, 黄文英, 苟平, 武達, 陈新元 (2008) 云南干热河谷能源植物的开发利用. 中国热带农 业, (1), 33-35.]

He YB, Lu PZ, Zhu T (2000) Causes for the formation of dry-hot valleys in Hengduan Mountain-Yunnan Plateau. Resources Science, 22, 69-72. (in Chinese with English abstract) [何永涁, 卢培泽, 朱䑣 (2000) 横断山一云南高原 干热河谷形成原因研究. 资源科学, 22, 69-72.]

Ji ZH, Liu GY, Duan YT, Sha YC, Li JZ (2003) Model of plantation restoration and ecological agriculture in fragile ecological environment in arid hot valley of Jinsha River. Journal of Soil Water Conservation, 17(5), 19-22. (in Chinese with English abstract) [纪中华, 刘光华, 段曰汤, 沙 毓沧, 李建增 (2003) 金沙江干热河谷脆弱生态系统植 被恢复及可持续生态农业模式. 水土保持学报, 17(5), 19-22.]

Ji ZH (2009) Ecological Agriculture in the Dry Hot Valleys: Research and Practice. Yunnan Science and Technology Press, Kunming. (in Chinese) [纪中华 (2009) 干热河谷生 态农业: 研究与实践. 云南科技出版社, 昆明.]

Jiang CY (2010) On the policy of rural road construction and advices for improvement. Journal of Science and Education, (4), 41. (in Chinese) [蒋春燕 (2010) 论我国农村“村村通 公路”政策及改进建议. 科教导刊, (4), 41.]

Jiang R, Fang R, Chen XP, Shen ZH (2012) Study on the influence and countermeasures of highway construction on biodiversity in the Three Parallel Rivers Region. Highway Traffic Science and Technology (Application Technology Edition), 12, 341-345. (in Chinese with English abstract) [姜睿, 房锐, 陈学平, 沈泽昊 (2013) 三江并流区公路建 设对生物多样性的影响分析及对策研究. 公路交通科技 (应用技术版), 12, 341-345.]
Jin ZZ, Ou XK (2000) The Vegetation of Dry Hot Valley of Yuanjiang River, Nujiang River, Jinsha River and Lancang River. Yunnan University Press \& Yunnan Science and Technology Press, Kunming. (in Chinese) [金振洲, 欧晓昆 (2000) 元江、怒江、金沙江、澜沧江干热河谷植被. 云 南大学出版社和云南科技出版社, 昆明.]

Jin ZZ (2002) Floristic Features of Dry-hot and Dry-warm Valleys, Yunnan and Sichuan. Yunnan Science and Technology Press, Kunming. (in Chinese) [金振洲 (2002) 滇川 干热河谷与干暖河谷植物区系特征. 云南科技出版社, 昆明.]

Jing R, Zhong XH, Liu SZ, Sha YC, Zhu HY, Yang SL (2000) Discussion on agricultural development in Yuanmou dry hot valley. Southwest China Journal of Agricultural Sciences, (2), 56-61. (in Chinese with English abstract) [景锐, 钟祥 浩, 刘淑珍, 沙毓沧, 朱红业, 杨顺林 (2000) 元谋干热 河谷区农业发展若干问题的探讨. 西南农业学报, (2), 56-61.]

Li BJ, Zhang SL, Hou CC (2013) Review on the research progress of ecological compensation. World Agriculture, (2), 11-21. (in Chinese with English abstract) [李碧洁, 张松林, 侯成成 (2013) 国内外生态补偿研究进展评述. 世界农 业, (2), 11-21.]

Li DM, Gao ZW, Fu X, Wu XQ, Wu G (2010) Ecological sensitivity of ecological functional area in Yunnan Province. Acta Ecologica Sinica, 30, 138-145. (in Chinese with English abstract) [李东梅, 高正文, 付晓, 吴晓青, 吴钢 (2010) 云南省生态功能类型区的生态敏感性. 生态学报, 30, 138-145.]

Li K, Liu FY, Yang ZY, Sun YY (2011) Study status and trends of vegetation restoration of dry-hot valley in Southwest China. World Forestry Research, 24(4), 56-60. (in Chinese with English abstract) [李昆, 刘方炎, 杨振寅, 孙 永玉 (2011) 中国西南干热河谷植被恢复研究现状与发 展趋势. 世界林业研究, 24(4), 55-60.]

Li K, Zhang CH, Cui YZ, Zhao YH, Shi YZ (2004) A study on the fitting afforestation tree species during converting the land for forestry in hot and arid valley of Jinsha River. Forest Research, 17, 555-563. (in Chinese with English abstract) [李昆, 张春华, 崔永忠, 赵一鹤, 施永泽 (2004) 金沙江干热河谷区退耕还林适宜造林树种篎选研究. 林 业科学研究, 17, 555-563.]

Li MY, Wang SY, Jiang R, Zhang W (2012) Analysis of land use/cover and landscape pattern change in the dry-hot valley (DHV) area: a case study in Derong County. Journal of Sichuan Agricultural University, 30(1), 60-66. (in Chinese with English abstract) [李苗裔, 王石英, 蒋容, 张伟 (2012) 干热河谷区土地利用/覆被和景观格局变化分析: 以得荣县为例. 四川农业大学学报, 30(1), 60-66.]

Li SL, Feng Z, Wang Y (2007) Application of restoration ecology theory in ecological restoration of major hydropower project in Southwest China. Journal of Disasters and Prevention, (2), 74-80. (in Chinese with English abstract) [李少丽, 丰瞻, 王宇 (2007) 恢复生态学理论在西南重 
大水电工程区生态修复中的应用探讨. 灾害与防治工程, (2), 74-80.]

Li XB (2009) Thinking on building an ecological compensation mechanism in Jinsha River watershed in China. Journal of Yunnan University of Finance and Economics, (2), 132138. (in Chinese with English abstract) [李晓冰 (2009) 关 于建立我国金沙江流域生态补偿机制的思考. 云南财经 大学学报, (2), 132-138.]

Li XQ (2013) The Impacts of Mineral Research Exploitation on Ecology and Environment: A Case Study about the Jiulong Section of Yalong River Basin. PhD Dissertation, Chengdu University of Science and Technology, Chengdu. [李璇琼 (2013) 矿产资源开发对生态环境的影响研究: 以雅袭江 流域九龙段为例. 博士学位论文, 成都理工大学, 成都.]

Li YH, Hu YM, Li XZ (2003) Research on the progress of road ecology. Chinese Journal of Applied Ecology, 14, 447-452. (in Chinese with English abstract) [李月辉, 胡远满, 李秀 珍 (2003) 道路生态研究进展. 应用生态学报, 14, 447452.]

Liang J, Liu Y, Ying LX, Li P, Xu Y, Shen ZH (2014) Do higher level roads have larger impacts on the mountain landscape? A case study of the Three Parallel Rivers region. Chinese Geographic Sciences, 24, 15-27.

Lin L (2011) The recovery and development of post disaster economy in post placement area of reservoir: a case in Yingpan County. Economic Research, (1), 148-150. (in Chinese with English abstract) [林霖 (2011) 水库后靠安 置地区灾后经济恢复与发展: 以青川县营盘乡为例. 经 济研究导刊, (1), 148-150.]

Liu G, Shen L, Sun SZ, Zhang FF (2007) Resource exploitation and industry sustainability development in the affected area of step hydro-power stations alongside the lower Jinshajiang River. Resources and Environment in the Yangtze Basin, 16, 565-570. (in Chinese with English abstract) [刘刚, 沈镭, 孙尚志, 张菲菲 (2007) 金沙江下游梯级电站开发影响 区域资源开发与产业可持续发展. 长江流域资源与环境, $16,565-570$.

Liu LH, Zhang JH (1988) A study on the dry valleys in Yunnan. Tropical Geography, 8, 355-362. (in Chinese with English abstract) [刘伦辉, 张建华 (1988) 云南干旱河谷 特点与治理途径. 热带地理, 8, 355-362.]

Liu Y, Shen LF, Wang T, Fang R, Jiang R, Shen ZH (2013) The intrusion pattern and influence factors of Eupatorium adenophorum along the roads in the Three Parallel Rivers Region, Northwest Yunnan. Highway Traffic Science and Technology (Application Technology Edition), 5, 284-288. (in Chinese with English abstract) [刘晔, 沈利峰, 王韬, 房锐, 姜睿, 沈泽昊 (2013) 滇西北三江并流地区公路沿 线紫茎泽兰的入侵格局及影响因素. 公路交通科技 (应用 技术版), 5, 284-288.]

Liu Y, Zhu XX, Shen ZH, Sun H (2016) Flora compositions and spatial differentiations of vegetation in dry valleys of Southwest China. Biodiversity Science, 24, 367-377. (in Chinese with English abstract) [刘晔, 朱釒金金錴, 沈泽吴, 孙
航 (2016) 中国西南干旱河谷植被的区系地理成分与空 间分异. 生物多样性, 24, 367-377.]

Lü YL (1998) Development and planning of ecotourism. Journal of Natural Resources, 13, 1-6. (in Chinese with English abstract) [吕永龙 (1998) 生态旅游的发展与规划. 自然 资源学报, 13, 1-6.]

Meng LL, Bao ZM (2004) Summarization of the study of migration for the reason of zoological environment. Journal of the Central University for Nationalities (Philosophy and Social Sciences Edition), 31, 48-52. (in Chinese with English abstract) [孟琳琳, 包智明 (2004) 生态移民研究综述. 中 央民族大学学报(哲学社会科学版), 31, 48-52.]

Ministry of Environmental Protection of the People's Republic of China (2015) The National Ecological Function Regionalization by the Chinese Academy of Sciences (Revised edition). [环境保护部 (2015) 中国科学院全国生态功能区划 ( 修编版 ). http://www.zhb.gov.cn/gkml/hbb/bgg/201511/ t20151126_317777.htm. (accessed 2016-04-20)]

Moseley RK, Tang Y (2006) Vegetation dynamics in the dry valleys of Yunnan, China, during the last 150 years: implications for ecological restoration. Journal of Plant Ecology, 30, 713-722. (in Chinese with English abstract) [Moseley RK, 唐亚 (2006) 云南干旱河谷 150 年来的植被变化研 究及其对生态恢复的意义. 植物生态学报, 30, 713-722.]

Mu J, Li ZB, Li P, Li Q, Hu L (2008) Study on ecological reconstruction technology of water dissipation zone in the reservoir area of the hydropower station in Jinsha dry-hot valley. Soil and Water Conservation Bulletin, 28, 172-176. (in Chinese with English abstract) [穆军, 李占斌, 李鹏, 李强, 胡琳 (2008) 金沙江干热河谷水电站库区消落带的生态 重建技术初探. 水土保持通报, 28, 172-176.]

Niu YF (1999) Sustainable tourism, ecotourism and implementation. Geographic Research, 18(2), 1-6. (in Chinese with English abstract) [牛亚菲 (1999) 可持续旅游、生态旅游 及实施方案. 地理研究, 18(2), 1-6.]

Ou XK (1994) Ecological condition and ecological construction in dry-hot valley of Yunnan Province. Resources and Environment in the Yangtze Basin, 3, 271-276. (in Chinese with English abstract) [欧晓昆 (1994) 云南省干热河谷地 区的生态现状与生态建设. 长江流域资源与环境, 3 , 271-276.]

Ou XK, Zhang ZM, Wang CY, Wu YC (2006) Vegetation of Meri Snow Mountain. Science Press, Beijing. (in Chinese) [欧晓昆, 张志明, 王崇云, 吴玉成 (2006) 梅里雪山植被 研究. 科学出版社, 北京.]

Peng H (2001) Plant resources and agricultural biodiversity in the southwest of China. Acta Botanica Yunnanica, 8(Suppl. XIII), 28-36. (in Chinese with English abstract) [彭华 (2001) 中国西南地区植物资源与农业生物多样性. 云南 植物研究, 8(增刊XIII), 28-36.]

Qiao XN, Yang YJ, Yang DG (2012) Research status of ecological compensation in river basin and key problem analysis. Progress in Geographical Science, 31, 395-402. (in Chinese with English abstract) [乔旭宁, 杨永菊, 杨德纲 
(2012) 流域生态补偿研究现状及关键问题剖析. 地理科 学进展, 31, 395-402.]

Sha YC, Ji ZH, Li JZ, Fang HD, Yang YX, Liao CF, Huang XQ (2006) The ecological environment of dry hot valley in Southwest China. Southwest China Journal of Agricultural Sciences, 19(Suppl.), 312-318. (in Chinese with English abstract) [沙毓沧, 纪中华, 李建增, 方海东, 杨艳鲜, 廖承 飞, 黄兴奇 (2006) 西南地区干热河谷生态环境问题. 西 南农业学报. 19(增刊), 312-318.]

Shen ZH, Zhang XS (2000) A quantitative analysis on the floristic elements of the Chinese subtropical region and their spatial patterns. Acta Phytotaxonomica Sinica, 38, 366-380. (in Chinese with English abstract) [沈泽吴, 张新时 (2000) 中国亚热带地区植物区系地理成分及其空间格局的数量 分析. 植物分类学报, 38, 366-380.]

Shi CC, Yong GW (2001) Present situation of the ecological environment and the countermeasures for reconstruction of the ecological environment of xerothermic and dry river valley areas in the upper reach of the Yangtze River. Southwest China Journal of Agricultural Sciences, 14(4), 114-118. (in Chinese with English abstract) [石承苍, 雍国 玮 (2001) 长江上游干热干旱河谷生态环境现状及生态 环境重建的对策. 西南农业学报, 14(4), 114-118.]

Sun H, Tang Y, Huang XJ, Huang CM (2005) Research status and development trend of dry river valley in Hengduan area. World Science and Technology Research and Development, 27(3), 54-61. (in Chinese with English abstract) [孙辉, 唐 亚, 黄雪菊, 黄成敏 (2005) 横断山区干旱河谷研究现状 和发展方向. 世界科技研究与发展, 27(3), 54-61.]

Sun XW, Du F, Wang J (2008) Study on community features of monsoon forest in the dry-hot valleys in Yuanjiang County. Journal of Southwest Forestry College, 28(1), 6-11. (in Chinese with English abstract) [孙胥雯, 杜凡, 王娟 (2008) 元江县干热河谷季雨林群落特征研究. 西南林学 院学报, 28(1), 6-11.]

Sun YM (2013) Study on the development of three-dimensional agriculture in Panzhihua City. China Agricultural Resources and Regional Planning, 6, 145-149. (in Chinese with English abstract) [孙亚明 (2013) 攀枝花市立体农业 发展研究. 中国农业资源与区划, 6, 145-149.]

Tikka PM, Hogmander H, Koski PS (2001) Road and railway verges sever as dispersal corridors for grassland plants. Landscape Ecology, 16, 659-666.

Tong HJ, Zeng GQ (1995) Environmental protection for developing mineral resources in Lan Cang Jiang Catchment. Yunnan Environmental Science, (3), 32-35. (in Chinese with English abstract) [童海京, 曾广权 (1995) 澜沧江流 域矿产资源开发的环境保护对策. 云南环境科学, (3), 32-35.]

Trombulak SC, Frissell C (2000) Review of the ecological effects of roads on terrestrial and aquatic ecosystem. Conservation Biology, 14, 18-30.

Wang JF, Hou CB (2013) Research on implementation framework and compensation model of ecological compensation mechanism in China: based on the perspective of the source of compensation funds. China's Population, Resources and Environment, 23(2), 23-29. (in Chinese with English abstract) [王军峰, 侯超波 (2013) 中国流域生态补偿机制 实施框架与补偿模式研究: 基于补偿资金来源的视角. 中国人口、资源与环境, 23(2), 23-29.]

Wang Y, Li P, Mu J, Bai D (2009) Study on countermeasures of ecological restoration of riparian zone of hydropower station reservoir area in Jinsha dry hot valley. Research on Soil and Water Conservation, 16, 141-144. (in Chinese with English abstract) [王勇, 李鹏, 穆军, 白丹 (2009) 金沙江 干热河谷水电站库区消落带生态修复对策研究. 水土保 持研究, 16, 141-144.]

Wu ZY (1980) Vegetation of China. Science Press, Beijing. (in Chinese) [吴征镒 (1980) 中国植被. 科学出版社, 北京.]

Xu JC, Zhang PF, Wang YH (2003) Land use and land cover in Lancang watershed of Yunnan. Acta Botanica Yunnanica, 25, 145-154. (in Chinese with English abstract) [许建初, 张佩芳, 王雨华 (2003) 云南澜沧江流域土地利用和覆 盖变化. 云南植物研究, 25, 145-154.]

Xu ZF, Tao GD, Yu PH, Wang YY (1985) An approach to the vegetational changes from Yuanjiang dry-hot valley of Yunnan in the last 500 years. Acta Botanica Yunnanica, 7, 403-412. (in Chinese with English abstract) [许再富, 陶国 达, 禹平华, 王耀尤 (1985) 元江干热河谷山地五百年来 植被变迁探讨. 云南植物研究, 7, 403-412.]

Yang LY, Wang J (2000) The development of tourism resources in the northwest of Yunnan Province. Ecological Economy, (12), 36-41. (in Chinese) [杨兰英, 王珏 (2000) 滇西北旅游资源及其开发. 生态经济, (12), 36-41.]

Yang QZ (2007) Study on the arid-valley scrubs in the upper reaches of Minjiang River. Journal of Mountain Science, 25, 1-32. (in Chinese with English abstract) [杨钦周 (2007) 岷 江上游干旱河谷灌丛研究. 山地学报, 25, 1-32.]

Yang QY, Zheng D, Liu YH (1988) Physico-geographic feature and economic development of the dry valleys in the Hengduan Mountains, Southwest China. Journal of Arid Land Resources and Environment, 2(2), 17-24. (in Chinese with English abstract) [杨勤业, 郑度, 刘燕华 (1988) 横 断山地区干旱河谷的自然特点及其开发利用. 干旱区资 源与环境, 2(2), 17-24.]

Yang SQ (2003) Jinsha River: the prospect of giant hydropower base in China. China Electric Power Enterprise Management, 9, 20-25. (in Chinese) [杨慎勤 (2003) 金沙 江: 我国巨型水电基地展望. 中国电力企业管理, 9, 20-25.]

Yang WQ, Wang KY, Song GY, Gong AD, He YR (2002) Analysis of ecological security in the typical area of Jinsha dry-hot valley. Chinese Journal of Ecological Agriculture, 10(3), 116-119. (in Chinese with English abstract) [杨万勤, 王开运, 宋光显, 宫阿都, 何毓蓉 (2002) 金沙江干热河 谷典型区生态安全问题探析. 中国生态农业学报, 10(3), 116-119.] 
Yang YX, Ji ZH, Fang DH, Bai DZ, Liao CF (2005) Study and preliminary evaluation on the benefit of models of compound eco-agriculture on dry slope land in Yuanmou dry hot valley. Research of Soil and Water Conservation, 12(4), 88-89, 99. (in Chinese with English abstract) [杨艳 鲜, 纪中华, 方海东, 拜得珍, 廖承飞 (2005) 元谋干热 河谷旱坡地复合生态农业模式效益研究初评. 水土保持 研究, 12(4), 88-89, 99.]

Yang YX, Ji ZH, Sha YC, Pan ZX, Fang DH, Bai DZ, Liao CF (2006) Study on benefits of soil and water conservation in the dry hot valley of dry land ecological agriculture model in Yuanmou. Journal of Soil and Water Conservation, 20(3), 70-73. (in Chinese with English abstract) [杨艳鲜，纪中华， 沙毓沧, 潘志贤, 方海东, 拜得珍, 廖承飞 (2006) 元谋 干热河谷区旱坡地生态农业模式的水土保持效益研究. 水土保持学报, 20(3), 70-73.]

Yang ZS, He YM, Li YH, Zhang YL, Wang YP (2004) Land use change and soil erosion control in dry-hot valley zone in the middle reaches of Jinsha River during 1960-2000: a case study in Binchuan County, Yunnan Province. Progress in Geography, 23(2), 16-25. (in Chinese with English abstract) [杨子生, 贺一梅, 李云辉, 张义琳, 王云鹏 (2004) 近 40 年来金沙江南岸干热河谷区的土地利用变化及其土 壤侵蚀治理研究: 以云南宾川县为例. 地理科学进展, 23(2), 16-26.]

Yang Y, Shen ZH, Han J, Zhongyong C (2016) Elevational gradients of plant species diversity along east and west slopes of Baima Snow Mountain in Southwest China. Forests, 7, doi: 10.3390/f7040089.

Ye YQ, Chen GJ, Fan H (2002) Research on the fragile ecological environment on resources and environment in the upper of the Minjiang River. Resources and Environment in the Yangtze Basin, 4, 383-387. (in Chinese with English abstract) [叶延琼, 陈国阶, 樊宏 (2002) 岷江上游脆弱生 态环境刍论. 长江流域资源与环境, 4, 383-387.]

Ying LX, Shen ZH, Chen JD, Fang R, Chen XP, Jiang R (2014) Spatiotemporal patterns of road network and road development priority in Three Parallel Rivers Region in Yunnan, China: an evaluation based on modified kernel distance estimate. Chinese Geographical Science, 24, 39-49.

Yu LJ, Du CJ (2008) Study on the sustainable development of agriculture in dry hot valley region. Rural Economy, (7), 67-68. (in Chinese with English abstract) [于丽娟, 杜长江 (2008) 干热河谷地区农业可持续发展研究. 农村经济, (7), 67-68.]

Zhang JP, Wang DJ (2000) The optimization strategy of agricultural ecological system in the dry hot valley of Yuanmou. Journal of Mountain Science, 18(2), 134-138. (in Chinese with English abstract) [张建平, 王道杰 (2000) 元 谋干热河谷区农业生态系统的优化对策. 山地学报, 18(2), 134-138.]

Zhang RZ (1992) The Dry Valleys of the Hengduan Mountains Region. Science Press, Beijing. (in Chinese) [张荣祖 (1992) 横断山区干旱河谷. 科学出版社, 北京.]
Zhang XB, Yang Z, Zhang JP (2003) Lithologic types on hill slopes and evegetation zoning in the Yuanmou hot-dry valley. Scientia Silvae Sinicae, 39(4), 16-22. (in Chinese with English abstract) [张信宝, 杨忠, 张建平 (2003) 元 谋干热河谷坡地岩土类型与植被恢复分区. 林业科学, 39(4), 16-22.]

Zhang YF (1998) Study on biological control technology in dry hot valley. Mountain Research, 16, 248-251. (in Chinese with English abstract) [张有富 (1998) 干热河谷气候区荒 坡生物治理技术. 山地研究, 16, 248-251.]

Zhang YG, Chen JW, Xu YJ (1989) Classification and optimal utilization of agricultural climate resources in the dry-hot valleys of southwestern China. Resources Science, (3), 1-6. (in Chinese) [张谊光, 陈纪卫, 徐渝江 (1989) 我国西南 干旱河谷农业气候资源的分类与合理利用. 资源科学, (3), 1-6.]

Zhang YY (2011) A study on the policies and laws on the ecological migration in western China. Forward Position, (20), 197-200. (in Chinese) [张云雁 (2011) 西部生态移民 的相关政策法律研究. 前沿, (20), 197-200.]

Zhang ZJ, Liu SQ, Cheng BX, Fan Y, Li Y (2006) Characteristics of land resources and characteristic ecological agricultural construction of dry-hot valley along Jinsha River. Journal of Sichuan Agricultural University, 24, 77-82. (in Chinese with English abstract) [张宗锦, 刘世全, 成本喜, 范宇, 李怡 (2006) 金沙江干热河谷土地资源特 点与特色生态农业建设途径探讨. 四川农业大学学报, 24, 77-82.]

Zhou JC (2011) Promote terrestrial ecological restoration in the dry hot valley of Jinsha River by means of hydropower development. Northwest Hydropower, (3), 1-3. (in Chinese) [周家骢 (2011) 以金沙江干流水电开发促进金沙江流域 干热河谷陆生生态修复. 西北水电, (3), 1-3.]

Zhou L (1996) Vegetation evolution in Yuanmou dry-hot valley since Quaternary period. Mountain Research, 14, 239-243. (in Chinese with English abstract) [周麟 (1996) 云南省元谋干热河谷的第四纪植被演化. 山地研究, 14 , 239-243.]

Zhou X, Zhang B, Liu G (2010) Monitoring og vegetation change in Yuanmou dry-hot valley based on remote sensing. Resources and Environment in the Yangtze Basin, 19, 1309-1313. (in Chinese with English abstract)[周旭, 张斌, 刘刚才 (2010) 元谋干热河谷近30年植被变化的遥感监 测. 长江流域植被与环境, 19, 1309-1313.]

Zhu H (2008) Distribution patterns of genera of Yunnan seed plants with references to their biogeographical significances. Advances in Earth Science, 23, 831-839. (in Chinese with English abstract) [朱华 (2008) 云南种子植物区系地理成 分分布格局及其意义. 地球科学进展, 23, 831-839.]

(责任编委：薛达元 责任编辑: 周玉荣) 